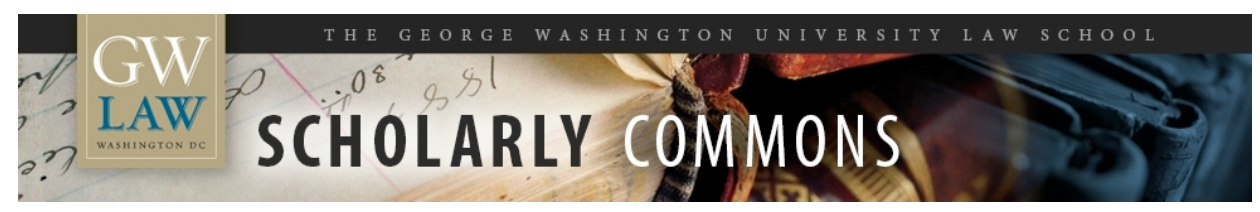

\title{
Rediscovering Board Expertise: Legal Implications of the Empirical Literature
}

Lawrence A. Cunningham

George Washington University Law School, lacunningham@law.gwu.edu

Follow this and additional works at: https://scholarship.law.gwu.edu/faculty_publications

Part of the Law Commons

\section{Recommended Citation}

Lawrence A. Cunningham, Rediscovering Board Expertise: Legal Implications of the Empirical Literature, 77 U. Cin. L. Rev. 465 (2008).

This Article is brought to you for free and open access by the Faculty Scholarship at Scholarly Commons. It has been accepted for inclusion in GW Law Faculty Publications \& Other Works by an authorized administrator of Scholarly Commons. For more information, please contact spagel@law.gwu.edu. 


\title{
REDISCOVERING BOARD EXPERTISE: LEGAL IMPLICATIONS OF THE EMPIRICAL LITERATURE
}

\author{
Lawrence A. Cunningham*
}

\begin{abstract}
This paper reviews and draws insights from recent empirical research in financial accounting on the value of director expertise for financial reporting quality. Among important consequences of Sarbanes-Oxley is an increase in the percentage of accounting experts on boards of directors, particularly on audit committees.

The research reviewed here documents the value of this expertise in promoting financial reporting quality measured in terms of "accounting earnings management" (artificial bookkeeping manipulations). These findings contrast with well-known evidence showing little value arising from director independence.

The research holds numerous implications and raises important questions, including the following:

1. It shows that accounting expertise is more valuable than other kinds of financial expertise, suggesting that the SEC should reconsider its definition of this concept.

2. Although accounting earnings management has declined since SOX, real earnings management (substantive business decisions taken to achieve accounting results, like delaying or accelerating investment in a new plant) may be rising. Do audit committee financial experts have a role to play in policing the latter?

3. What role do such experts have in determining the degree of conservatism that a firm uses in its financial reporting, demand for which may differ as among shareholders, bondholders, employees and others?

4. It is customary to see independence and expertise as trade offs. This may be correct when expertise arises from insider status, but incorrect when the expertise is substantive knowledge in a discipline, such as accounting.

5. Law has traditionally encouraged director independence and discouraged expertise but, this research suggests, that may be backwards and certainly requires reconsideration.
\end{abstract}

\footnotetext{
* Professor of Law, George Washington University. Thanks to Richard Baker, Donald Clarke, Renee Jones, Troy Paredes and Robert Prentice. This inquiry was prepared to appear as a Chapter in The New Corporate Governance, edited by Professor Paredes, and forthcoming from Cambridge University Press in 2008.
} 


\title{
REDISCOVERING BOARD EXPERTISE LEGAL IMPLICATIONS OF THE EMPIRICAL LITERATURE
}

\author{
Lawrence A. Cunningham
}

People are rediscovering the value of expertise on corporate boards of directors. The rediscovery occurs after several decades of celebrating independent directors under the guise of the "monitoring model" of boards. While independence remains fashionable, and the Sarbanes-Oxley Act of 2002 (SOX) continues its longstanding promotion, SOX also requires companies to disclose whether their boards have expertise on the board audit committee and, if not, why not. ${ }^{1}$ This hastens an inchoate ten-year trend favoring expertise. The value of expertise is supported by theory and empirical research. Accidents of political history appear to explain its subordination, until recently, to independence.

As a matter of theory, board expertise harmonizes with basic division of labor principles, yet little attention is paid to the specific expertise that directors offer. The most prominent model of director expertise, developed during the rise of the monitoring board, envisioned an expertise in "decision control." ${ }^{2}$ But this views boards as monoliths and hides the significance of individuals in group decision making. ${ }^{3}$ Accompanying the rise of the monitoring board and its privileged place for independence was the rise of the board committee, especially the audit committee. Although committees have designated functions, until recently the focus has been on member independence rather than expertise benefiting from division of labor.

As an empirical matter, the value of expertise is supported by a large body of research. Most strikingly, research shows that accounting expertise is valuable in promoting audit committee effectiveness, while general financial and other expertise contribute less value. The rise of independence and its displacement of expertise were due largely to periodic needs to quell political disputes or respond to crisis. The appeal to independence helped generate consensus. The rediscovery of the value of expertise appears after an abundance of empirical research showing that independence on boards of directors is of uncertain value at best.

Despite this rediscovery of the value of expertise, no statement of purpose accompanies the new imperatives for expertise. Legal doctrines developed over several decades, based on the independence construct, should be reviewed to adapt to increased value resulting from reintroduction of expertise into the boardroom. Restoring expertise

\footnotetext{
${ }^{1}$ Sarbanes-Oxley Act of 2002 §301, codified at 15 U.S.C. §78j-1(m)(2) (2007).

2 Eugene F. Fama \& Michael C. Jensen, Separation of Ownership and Control, 26 J.L. \& ECON. 301, 315 (1983).

${ }^{3}$ See Darian M. Ibrahim, Individual or Collective Liability for Corporate Directors?, 93 IowA L. REV. (forthcoming 2008).
} 
requires revisiting basic conceptions of corporate governance, including some encrusted principles of state corporation law and some recently developed gestures in securities regulation.

After a brief summary of the rise of board independence showing its political roots and uncertain economic value, analysis below considers the origins and current state of interest in director expertise. This includes a review of the considerable body of recent empirical evidence showing high value of accounting expertise among directors on audit committees. Analysis suggests that desired expertise for board audit committees centers on accounting expertise, rather than other types. SOX rightly contemplated that kind of expertise but, under pressure, the Securities and Exchange Commission instead adopted an expansive conception of expertise that dilutes its value.

Discussion then explores more complex challenges that arise from rediscovering the value of expertise. First, the purpose of accounting expertise on audit committees is not self-evident. One issue concerns what scope of burden those experts bear: whether their enlistment to control "accounting earnings management" (artificial bookkeeping manipulations) extends to a mandate to control "real earnings management" (substantive business decisions taken to generate desired bookkeeping consequences). Another is to whom audit committee accounting experts should be beholden, a $21^{\text {st }}$ century twist on last century's debate concerning for whom managers are trustees. The current issue hinges on the meaning and beneficiaries of conservatism in accounting, considering competing demands for relative conservatism from varying corporate constituencies.

Second, it is customary to see independence and expertise as trade offs. This view seems correct when expertise arises from insider status but incorrect when the expertise is substantive knowledge in a discipline. It should be possible for a director to be both an expert and independent. Indeed, empirical evidence shows that the combination of independence and expertise is uniquely valuable and should be encouraged. Yet while law has long promoted independence, it discourages expertise. This appears to reflect unintended doctrinal consequences of the decades-long independence bias. Accordingly, the rediscovered value of expertise demands doctrinal adjustments so that courts can bring law into line with what is known to work in corporate governance.

\section{The Politics AND ECONOMICS OF INDEPENDENCE}

Two schools of thought have influenced conceptions of the corporation: a private law account based in trust and contract law, with shareholders as beneficiaries, versus a public law account based on state concessions of charter grants with multiple constituencies. During the $20^{\text {th }}$ century, the dominant view came to center on private shareholder interests to be advanced by boards - although standard formulations of directorial duty retain vestiges of the dueling schools when invariably announcing that directors must act in the interests of "the corporation and its shareholders."

\footnotetext{
${ }^{4}$ See William T. Allen, Our Schizophrenic Conception of the Business Corporation, 14 CARdOzo L. REv. 261 (1992).
} 


\section{A. Politics}

The assumptions of private ordering were first tested amid the economic upheavals of the 1930s and ensuing regulatory frenzy and academic debates. A series of exchanges from 1931 to 1935 between Professors Adolph Berle and Merrick Dodd reflect the familiar positions. ${ }^{5}$ Professor Berle saw the corporation as involving a relinquishment of control by shareholders to corporate managers and believed that the resulting separation of ownership from control required imposing trust-like duties on managers to act for shareholder benefit. Professor Dodd, accepting that separation existed, proposed to fill it not with managerial duties to shareholders but with managerial duties to various corporate constituencies that included employees and communities. ${ }^{6}$

With a nod to Dodd, contemporaneous legislative reforms occurred at the federal level. But they mostly embraced Berle's stance, with the role for independent directors to promote investor interests, not broader public ones. The political role of independent directors thus appears at this early stage, reflecting how the new federal securities laws were "a pragmatic compromise between proponents of direct federal control over corporations through chartering [and] those who sought to leave all regulation of corporations to the states." 7

This model was tested again during the turmoil from the mid-1960s to the late 1970s. Investigations into the Watergate scandal revealed that US corporations made extensive and illicit bribes to foreign officials—without accurately accounting for them. ${ }^{8}$ Flurries of SEC consent orders mandated corporate governance reforms, with an emphasis on installing independent directors. ${ }^{9}$ This began a custom, which continues today, of responding to corporate crisis by looking to independent directors. Then,

\footnotetext{
5 Adolph A. Berle, Corporate Powers as Powers in Trust, 44 HARV. L. REV. 1049 (1931); E. Merrick Dodd, Jr., For Whom Are Corporate Managers Trustees?, 45 HARV. L. REV. 1145 (1932); Adolph A. Berle, For Whom Corporate Managers Are Trustees: A Note, 45 HARV. L. REV 1365 (1932); E. Merrick Dodd, Jr., Is Effective Enforcement of the Fiduciary Duties of Corporate Managers Practicable?, 2 U. CHI. L. REV. 194 (1935).

${ }^{6}$ This is obviously an over-generalized summary of these stances, which are far more complex and must be understood in their historical context. For those purposes, see William W. Bratton \& Michael L. Wachter, Shareholder Primacy's Corporatist Origins: Adolf Berle and 'The Modern Corporation”, Research Paper (Oct. 9, 2007), available at http://ssrn.com/abstract=1021273.
}

${ }^{7}$ See Roberta S. Karmel, The Independent Corporate Board: A Means to What End?, 52 GEO. WASH. L. REV. 534 (1984).

${ }^{8}$ E.g, SEC v. ITT Corp., 1979 Fed. Sec. L. Rep. (CCH) ๆ 96,948 (D.D.C. Aug. 8, 1979); SEC v. Lockheed, [1975-76 Transfer Binder] Fed. Sec. L. Rep. (CCH) I 95,509 (D.D.C. Apr. 13, 1976).

9 See Arthur F. Mathews, Recent Trends in SEC Requested Ancillary Relief in SEC Level Injunctive Actions, 31 Bus. LAw. 1323 (1976); Lewis D. Solomon, Restructuring the Corporate Board of Directors: Fond Hope, Faint Promise?, 76 MicH. L. REV. 581 (1978). 
Congress banned such bribes and mandated systems of internal control and maintaining books and records to promote faithful financial reporting. ${ }^{10}$

The period's lack of directorial oversight is understandable, however, for Delaware courts had told directors a decade earlier (in 1963) that they had no duty to maintain internal control or to discover mis-reporting within corporations whose boards they occupied. ${ }^{11}$ Joining Congress, in the wake of the bribery scandals, Delaware courts began a decades-long process of rewarding the use of independent directors. In opinions arising out of related derivative litigation, they accorded special deference to decisions of independent directors serving on special litigation committees and made this role pivotal to the law of demand futility in derivative litigation. ${ }^{12}$

Amid a campaign for corporate social responsibility led by Ralph Nader and Joel Seligman, ${ }^{13}$ Melvin Eisenberg ${ }^{14}$ focused inquiry on variation between state law, which said that boards were to manage the corporation, and practice, which showed that they did no such thing. ${ }^{15}$ A brilliant political compromise resulted in the demise of the advisory board model—seen as non-functional—and its replacement with the monitoring board and a heightened emphasis on independence and subordination of expertise. Yet no consensus existed concerning exactly what independent directors were to do ${ }^{16}$ —or how independence was to be defined. ${ }^{17}$

The 1980s takeover boom gave independent directors a specific role. Delaware courts, continuing a pattern dating at least to the bribery scandal litigation, strengthened

${ }^{10}$ Foreign Corrupt Practices Act, 15 U.S.C. § 78m(b)(2); see SEC v. World-Wide Coin Investments, Ltd., 567 F. Supp. 724 (N.D. Ga. 1983).

${ }^{11}$ Graham v. Allis-Chalmers Mfg. Co., 188 A.2d 125 (Del. 1963).

${ }^{12}$ Zapata v. Maldanado, 430 A.2d 779 (Del. 1981); see also Auerbach v. Bennett, 393 N.E.2d 994 (N.Y. 1979).

13 See Ralph NAder ET AL., TAMing the Giant Corporation 123-28 (1976).

${ }^{14}$ Melvin A. Eisenberg, The Structure of the Corporation: A Legal Analysis (1976).

${ }^{15}$ See William O. Douglas, Directors Who Do Not Direct, 47 HaRV. L. Rev. 1305 (1934); Myles Mace, DiReCTORS: Myth AND ReAliTY (1971); Myles L. Mace, Directors: Myth and Reality-Ten Years Later, 32 RUTGERS L. REV. 293 (1979).

${ }^{16}$ The monitoring model and its independent directors arrived with critics, including well-chronicled debates within the American Law Institute (ALI) and between the ALI and the Business Roundtable and American Bar Association. For a thorough analytical review of this history, Jeffrey N. Gordon, The Rise of Independent Directors in the United States, 1950-2005: Of Shareholder Value and Stock Market Prices, 59 STAN. L. REV. 1465 (2007).

17 See Donald C. Clarke, Three Models of the Independent Director, 32 DEL. J. CoRP. L. 73 (2007). 
the appeal of independent directors by increasingly deferring to their decisions. ${ }^{18}$ Using independent directors insulated from judicial review self-interested transactions, ${ }^{19}$ cashout mergers, ${ }^{20}$ adoption of poison pills, ${ }^{21}$ resisting hostile takeover threats ${ }^{22}$ and simply "saying no" to them. ${ }^{23}$ Delaware law eschewed the question of director expertise, although the New Jersey Supreme Court famously announced that the duty of care requires directors to examine and understand a corporation's financial statements. ${ }^{24}$

By the 1990s, director independence was heralded to solve virtually all corporate governance challenges. ${ }^{25}$ The construct became a routine policy tool, used in numerous contexts. $^{26}$ Independence was to promote optimal compensation and recruiting despite directors lacking expertise in the relevant subjects. Some promoted "perspective and diversity" on boards, ${ }^{27}$ which may be seen as a kind of expertise, such as sensitivity to the interests of other constituencies, although it remained true that no expertise was sought on behalf of traditional, shareholder, constituencies State courts made using independent directors irresistible to corporations, giving deference to decisions that were widely condemned and hard to defend so long as made by independent directors. ${ }^{28}$

These ambitions continued in response to the parade of accounting scandals that erupted in the early 2000s-epitomized by revelation that Enron Corp., nominally the $7^{\text {th }}$ largest US corporation-were elaborate frauds. In their immediate aftermath, politically astute corporate leaders sought to avert regulation by advocating reforms that

18 On the previous pattern, see Lawrence E. Mitchell, The Trouble with Boards (Sept. 9, 2005) (unpublished manuscript) (principal role of independent directors before the 1970s, and to a lesser extent since, was sanitizing interested-director transactions and providing insulation from liability)

19 Marciano v. Nakash, 535 A.2d 400 (Del. 1987); see also Fliegler v. Lawrence, 361 A.2d 218 (Del. 1976).

${ }^{20}$ Weinberger v. UOP, Inc., 457 A.2d 701 (Del. 1983).

${ }^{21}$ Moran v. Household Int'l, Inc., 500 A.2d 1346 (Del. 1985).

${ }^{22}$ Unocal v. Mesa Petroleum, Inc., 493 A.2d 946 (Del. 1985).

${ }^{23}$ Paramount Communications, Inc. v. Time, Inc., 571 A.2d 1140 (Del. 1990).

${ }^{24}$ Francis v. United Jersey Bank, 432 A.2d 814 (N.J. 1981).

${ }^{25}$ See Richard A. Epstein, In Defense of the Corporation, 2004 NZ L. REV. 707, 719 (2004).

26 These included concerning (a) compensation disclosure (1992); (b) tax deductibility of certain compensation expenses (1994); and (c) application of short swing profit rules (1996).

${ }^{27}$ See Martin Lipton \& Jay W. Lorsch, A Modest Proposal for Improved Corporate Governance, 48 BuS. LAW. 59, 67-68 (1992).

28 See, e.g., Brehm v. Eisner, 746 A.2d 244 (Del. 2000); In re Walt Disney Co., 907 A.2d 693 (Del. Ch. 2005). 
concentrated on increasingly using independent directors. ${ }^{29}$ While this effort failed, when Congress intervened by passing SOX, it continued the habit of celebrating director independence. Despite continuing resort to independent directors for political purposes or in response to crisis, there has never been much evidence of related benefits. ${ }^{30}$

\section{B. Economics}

At Enron and firms that committed other frauds of the early 2000s, boards were endowed with abundant independence, yet failed miserably. This is unsurprising considering a comprehensive 1999 survey of empirical studies that found little correlation between independence and corporate performance. ${ }^{31}$ In fact, as two recent updated reviews of this literature attest, the considerable evidence shows at beast weak correlation between board independence and corporate performance. ${ }^{32}$

Evidence is slightly stronger of correlations between director independence and specific tasks. Some evidence suggests that independence associates with prudent cash management and facilitating or resisting changes in corporate control. Independent directors may be better at firing sub-par managers, although evidence is slight and scattered.

There is little or no evidence that independent directors achieve greater gains for takeover targets or adopt different defensive profiles than other directors. Evidence conflicts on whether firms with independent boards are less likely to make value reducing takeover bids; any effect that appears is small. Research does not show any particular effects of independence on CEO compensation. Evidence does show a relation between board and audit committee independence-and expertise-and various measures of financial reporting quality (but that gets ahead of the story and will be discussed in the next Part).

While scholars generally construe the empirical evidence as not supporting claims that independent directors improve firm performance, that conclusion is not inevitable. Professor Jeffrey Gordon reinterprets the empirical relations by explaining the data on other grounds. ${ }^{33}$ This reinterpretation emphasizes diminishing returns to independence,

\footnotetext{
${ }^{29}$ See Stephen M. Bainbridge, A Critique of the NYSE's Director Independence Listing Standards, 30 SEC. REG. L.J. 370 (2002).

${ }^{30}$ See Laura Lin, The Effectiveness of Outside Directors as a Corporate Governance Mechanism: Theories and Evidence, 90 Nw. U. L. REV. 898 (1996).

${ }^{31}$ Sanjai Bhagat \& Bernard Black, The Uncertain Relationship Between Board Composition and Firm Performance, 54 Bus. LAW. 921 (1999); Sanjai Bhagat \& Bernard Black, The Non-Correlation Between Board Independence and Long-Term Firm Performance, 27 J. CORP. L. 231 (2002).

${ }^{32}$ The comprehensive reviews are Gordon, supra note __ and Robert A. Prentice \& David B. Spence, Sarbanes-Oxley as Quack Corporate Governance: How Wise is the Received Wisdom?, 95 GEO. L.J. 1843 (2006). Readers are referred to these works for citations to the research summarized in the next paragraph.

${ }^{33}$ Gordon, supra note
} 
because the data all look at changes in independence levels during periods after the construct had achieved normative status. The more important effects may be systemic, not unique to individual enterprises, and include more accurate stock prices and fuller financial disclosure that benefits all enterprises, according to Professor Gordon.

Another basis for reinterpreting the studies that examine corporate performance is how independent directors may contribute other skills such as promoting compliance or advancing social interests. This view seems plausible given how some original proponents of the monitoring board sought to promote compliance amid the bribery scandals and some current champions continue to seek compliance, especially with financial reporting requirements. ${ }^{34}$ These purposes may not translate into measurable improvements in corporate performance (indeed Professor Daniel Fischel warned of, and some proponents advocated, the opposite). ${ }^{35}$

On the other hand, this reinterpretation fits uneasily alongside studies showing weak correlations between independence and specific tasks, suggesting yet other possibilities: that nominal independence was subverted by managerial control over the appointments process ${ }^{36}$ or that nominal independence transforms into structural bias once an outsider joins a board. ${ }^{37}$ In any event, the independent director remains a powerful norm, despite initial and continuing disagreement about its purposes or effects. However, there is an emerging appeal for expertise that promises to alter conventional attitudes towards boards in corporate governance. ${ }^{38}$

\section{THE EMERGING APPEAL FOR EXPERTISE}

The fascination for independent directors that arose in the 1970s brought increased attention to board committees, especially audit, compensation and nominating committees. ${ }^{39}$ This attention implicitly recognized the value of division of labor on a board of directors. Yet there was little discussion of the qualifications that would be put

${ }^{34}$ See Prentice \& Spence, supra note _ _ at 1868.

${ }^{35}$ See Daniel J. Fischel, The Corporate Governance Movement, 35 VAND. L. REV. 1259 (1982).

${ }^{36}$ See William W. Bratton \& Joseph A. McCahery, Regulatory Competition, Regulatory Capture, and Corporate Self-Regulation, 73 N.C.L. REV. 1861, 1867-68 (1995).

${ }^{37}$ See James D. Cox \& Donald E. Schwartz, The Business Judgment Rule in the Context of Termination of Derivative Suits by Independent Committees, 61 N.C. L. REv. 541, 542-43 (1983).

${ }^{38}$ Previous efforts to overcome the independence obsession have called for accountability, although that is not the same as the call for expertise. E.g., Ronald J. Gilson \& Reinier Kraakman, Reinventing the Outside Director: An Agenda for Institutional Investors, 43 STAN. L. REV. 863, 865 (1991).

${ }^{39}$ See ABA Comm. on Corporate Laws, Corporate Director's Guidebook, 33 Bus. LAw. 1591, 1619-20 (1978); Bus. Roundtable, Statement, The Role and Composition of the Board of Directors of the Large Publicly Owned Corporation, 33 Bus. LAW. 2083, 2108-10 (1978). 
to use by these committees. Instead, the motivation was to put certain kinds of decisions in the hands of independent directors, whether they had expertise or not.

A changing of the guard is afoot, with expertise becoming at least as important as independence in corporate governance. That change was led by stock exchanges in the late 1990s and reinforced with SOX's encouragement of expertise on audit committees in 2002. In the five years since SOX, the percentage of accountants on board audit committees has doubled and the trend appears likely to continue. ${ }^{40}$

\section{A. Audit Committees}

It has long been recognized that the audit committee is the most important board committee. $^{41}$ Proposals for mandatory audit committees date to the late 1930s and early $1940 \mathrm{~s}^{42}$ Interest resumed in the late 1960s and gathered momentum through the 1970s. ${ }^{43}$ In the 1970s, the SEC encouraged using independent directors on audit committees; ${ }^{44}$ adopted rules requiring companies to disclose whether or not they had an audit committee; $^{45}$ and published guidelines addressing audit committee attributes. ${ }^{46}$ As a result, audit committee use expanded dramatically from the mid-1960s, when they were relatively rare, to the mid-1970s, when they became commonplace. ${ }^{47}$

${ }^{40}$ See Stephen Taub, Audit Committees Embracing Accountants, CFO MAGAZINE, CFO.com (Sept. 21, 2007) (referring to a report from Huron Consulting Group).

${ }^{41}$ See PricewaterhouseCoopers, What Directors Think Annual Survey (2005).

${ }^{42}$ See In re McKesson \& Robbins, Inc., Exchange Act Release No. 2707, [1940 Transfer Binder] Fed. Sec. L. Rep. (CCH) I 72,020 (Dec. 5, 1940); Edward F. Greene \& Bernard B. Falk, The Audit Committee: A Measured Contribution to Corporate Governance [and] A Realistic Appraisal of Its Objectives and Functions, 34 Bus. LAW. 1229, 1233 n.16 (1979) (noting 1939 NYSE proposal).

${ }^{43}$ See Greene \& Falk, supra note — Subcomm. on Oversight \& Investigations of the H. Comm. on Interstate and Foreign Commerce, 94th Cong., Report on Federal Regulation and Regulatory Reform 29-42 (Subcomm. Print 1976).

${ }^{44}$ See SEC, Standing Audit Committees Composed of Outside Directors, [1971-1972 Transfer Binder] Fed. Sec. L. Rep. (CCH) ๆ 78,670, at 81,424 (No. 9548, Mar. 23, 1972).

${ }^{45}$ Item 8(e), Schedule 14A, 17 C.F.R. §240.14a-101 (1978).

${ }^{46}$ SEC, Notice of Amendments to Require Increased Disclosure of Relationships between Registrants and Their Independent Public Accountants, 40 Fed. Reg. 1010 (1974), reprinted in [Accounting Series Release Transfer Binder] Fed. Sec. L. Rep. (CCH) I 72,187, at 62,394 (No. 11147, Dec. 20, 1974); Proposed Rules Relating to Shareholder Communications, Shareholder Participation in the Corporate Electoral Process and Corporate Governance Generally, Exchange Act Release No. 14,970, 15 SEC Docket 291 (July 18, 1978).

${ }^{47}$ See Gordon, supra note __ at n. 211 (citing evidence that in 1967 from 1/3 to 1/5 of companies boasted audit committees whereas by 1977 nearly all did). 
The NYSE adopted a 1977 listing requirement mandating independent directors on audit committees. ${ }^{48}$ The provision offered a capacious conception of independence. It allowed persons having "customary" commercial and professional relationships with the company, so long as this did not otherwise pose a threat to independent judgment. This formulation may strike contemporary students as nearly empty given current sensibilities about independence. But at the time, the provision was a significant change and the "customary relationships" exception was not seen to nullify the innovation. ${ }^{49}$ The other exchanges followed the NYSE's lead during the 1980s. ${ }^{50}$

A series of audit failures in the early 1980s sparked interest in accounting aspects of corporate governance. In 1987, the AICPA and others sponsored the National Commission on Fraudulent Financial Practices. In addition to founding COSO—which became the chief architect of corporate internal controls ${ }^{51}$-it produced a Report of the National Commission on Fraudulent Financial Reporting. ${ }^{52}$ This Commission, named for Chairman James Treadway, recommended that boards be required to have independent audit committees and suggested the high value of accounting expertise for audit committee members. No official action was taken on the recommendations as the late 1980s turned into the roaring 1990s.

In 1994, the Public Oversight Board of the SEC Practice Section of the AICPA formed an advisory panel to give auditing a central role in corporate governance and return auditing to an important place in society. ${ }^{53}$ It urged that audit committees be informed as to the appropriateness of a company's accounting principles and the degree of conservatism in their application. ${ }^{54}$ This demand for information is a precursor to ensuing calls for actual knowledge—expertise—on audit committees.

Those calls began in the late 1990s, when SEC Chairman Arthur Levitt launched a campaign to improve corporate governance by emphasizing expertise, not mere

\footnotetext{
${ }^{48}$ Proposed Rule Change by Self-Regulatory Organizations, 42 Fed. Reg. 8737 (Feb. 11, 1977); Securities Exchange Act Release No. 13,346 (Mar. 9, 1977), 11 SEC Docket 1945, 1946 (1977); Order Approving Proposed Rule Change, 42 Fed. Reg. 14,793 (Mar. 16, 1977).

${ }^{49}$ See Karmel, supra note __ at ___ (citing Securities Exchange Act Release No. 13,346 (Mar. 9, 1977), 11 SEC Docket 1945, 1946 (1977).

${ }^{50}$ See Karmel, supra note _ _ text at notes 69-70.

${ }^{51}$ See www.coso.org (COSO stands for the Committee of Sponsoring Organizations that established the working group).

${ }^{52}$ Report of the NATional Commission on Fraudulent FinAnCial Reporting (1987), available at: www.coso.org/Publications/NCFFR.pdf.

${ }^{53}$ See www.publicoversightboard.org/about.htm

${ }^{54}$ See Public Oversight BoARd, 1994 Report.
} 
independence. ${ }^{55}$ He urged companies to recruit more audit committee members with financial experience. A group he empanelled echoed the point, urging that audit committees have at least three financially literate members and one with financial management experience. ${ }^{56}$ The NYSE and Nasdaq adopted these recommendations under rules, still in effect, requiring all audit committee members to be financially literate and show financial sophistication, demonstrated by oversight responsibilities, past experience, or professional certification. ${ }^{57}$

SOX reformed structural features as well as highlighting abstract independence and substantive expertise. Previously, power over the audit function was lodged with outside auditors and internal management, with limited audit committee oversight. ${ }^{58}$ Managers hired, fired and paid auditors, so auditors were beholden to them-not to the committee. An independent and expert committee under those circumstances might be worth little. SOX puts the committee in charge and vests it with important powers. ${ }^{59}$ This alters the monitoring model, equipping independent-and now expert-directors with power they never had before. ${ }^{60}$

SOX injects expertise into the audit committee indirectly. It requires companies to disclose whether the audit committee boasts expertise or not (and if not, why not). Even so, this gesture towards expertise is a dramatic change from the traditional habit of simply adding formal independence (although SOX indulges that habit too, as noted). ${ }^{61}$

55 See Arthur Levitt, The "Numbers Game", Remarks at the New York University Center for Law and Business (Sept. 28, 1998), available at www.sec.gov/news/speeches/spch220.txt.

${ }^{56}$ See Ira M. Millstein, Introduction to the Report and Recommendations of the Blue Ribbon Committee on Improving the Effectiveness of Corporate Audit Committees, 54 Bus. LAW. 1057 (1999). The group also followed the tradition of boosting independence, including by recommending eliminating the allowance of the "customary relationships” loophole appearing in previous definitions.

57 NYSE Listed Company Manual 303.01(B)(2)(a) and 303.01(B)(2)(b)-(c); NASD By-Laws, Art. 9, Sec. 5; NASD Marketplace Rules, Sec. 4350(d)(1)-(2). NYSE listing rules also currently require compensation and nominating committees, both with independent directors, but are silent as to desired expertise. NYSE, Inc., Listed Company Manual §303A.04-.05 (2007).

58 On the problems embedded in the old relationship, see Melvin A. Eisenberg, Legal Models of Management Structure in the Modern Corporation: Officers, Directors and Accountants, 63 CAL. L. REV. 375 (1975).

59 Sarbanes-Oxley Act of 2002 §301, codified at 15 U.S.C. §78j-1(m)(2) (2007); see Strengthening Requirements Regarding Auditor Independence, Securities Act Release No. 8183, Exchange Act Release No. 47,265, Public Utility Holding Company Act Release No. 27,642, Investment Company Act Release No. 25,915, Investment Advisers Act Release No. 2103, 68 Fed. Reg. 6006 (Feb. 5, 2003).

${ }^{60}$ William W. Bratton, Enron, Sarbanes-Oxley and Accounting: Rules versus Principles versus Rents, 48 VILL. L. REV. 1023, 1034-36 (2003).

${ }^{61}$ Sarbanes-Oxley Act of 2002 §301, codified at 15 U.S.C. §78j-1(m)(2) (2007) ("to be considered to be independent for purposes of this paragraph, a member of an audit committee of an issuer may not, other than in his or her capacity as a member of the audit committee, the board of directors, or any other board 
SOX conceives of the required audit committee expertise in explicit, focused terms, measuring expertise by formal training and experience in accounting. ${ }^{62}$ But SOX also directed and deferred to the SEC to define the requisite expertise in implementing the statute.

In its first proposed definition, the SEC followed SOX's language to draw expertise narrowly, emphasizing knowledge of accounting through extensive experience in the field. ${ }^{63}$ This conception is now described in the literature as an "accounting financial expert"-only professional accountants qualified. Critics objected to the narrow definition. Some claimed that, under it, financial heavyweights like Warren Buffett and Alan Greenspan would not qualify as experts; others said it would be hard to attract people who met the narrow definition and that the narrow skills would absorb limited resources needed to recruit other persons with other desirable skill sets. ${ }^{64}$

In response to objections, the SEC broadened the definition beyond accounting experience to include experience in finance, financial statement analysis or evaluation and even supervision of accounting and financial executives or personnel. ${ }^{65}$ The revised definition resembles the definitions of expertise adopted a decade earlier by the NYSE and Nasdaq. No longer limited to professional accountants, nearly anyone in business qualifies-managers of other companies, investment bankers, commercial bankers and venture capitalists. Reflecting this broad definition, three categories of audit committee experts are now described in the literature: accounting experts, non-accounting financial experts, and non-financial experts.

\section{B. Evidence}

committee (i) accept any consulting, advisory, or other compensatory fee from the issuer; or (ii) be an affiliated person of the issuer or any subsidiary thereof.”).

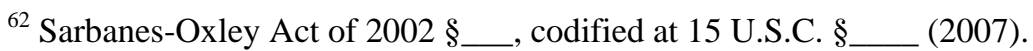

63 SEC Release (Oct. 22, 2002). The SEC's proposed definition of financial expert mimicked SOX's language, saying SOX requires the SEC, in defining, financial expert:

to consider whether a person has, through education and experience as a public accountant or auditor or a principal financial officer, or controller, or principal accounting officer of an issuer, or from a position involving the performance of similar functions: (1) an understanding of [GAAP] and financial statements; (2) experience in (a) the preparation or auditing of financial statements of generally comparable issuers and (b) the application of such principles in connection with the accounting for estimates, accruals and reserves; (3) experience with internal accounting controls; and (4) an understanding of the audit committee functions.

Id.

${ }^{64}$ See C. Bryan-Low, Defining Moment for SEC: Who’s a Financial Expert?, WALL ST. J. (Dec. 9, 2002).

65 SEC Release (Jan. 23, 2003) (coining the designation “audit committee financial expert”). 
Empirical evidence on the correlation between director independence and corporate performance reveals weak links, as discussed above. ${ }^{66}$ The exception is a welldeveloped body of evidence demonstrating a strong positive correlation between director independence and financial reporting quality (measured in various ways, as discussed below). ${ }^{67}$ Researchers and theorists struggled to interpret this exception and soon ascertained that it operates through audit committees. ${ }^{68}$ Increasingly, evidence shows that this correlation strengthens significantly when accounting experts serve on audit committees (and strengthens incrementally when audit committee members have other expertise encompassed in the SEC's expansive, criticism-induced, definition).

Research has long examined the correlation between board level independence and various proxies for financial reporting quality. Evidence shows a strong negative correlation between relative board independence and accounting fraud. ${ }^{69}$ A similar pattern appears in relation to the probability of financial misreporting, with pending SEC enforcement actions and shareholder lawsuits serving as a proxy. ${ }^{70}$ These results are corroborated in tests that use other proxies of financial statement reliability, including the presence of abnormal accruals and other signs of earnings management. ${ }^{71}$ Similar results were obtained when the independence of audit committees was examined discretely,

\footnotetext{
${ }^{66}$ See supra text accompanying notes

${ }^{67}$ See Prentice \& Spence, supra note _ _ at 1869 ("the vast bulk of existing empirical studies indicates that more board independence does translate into more accurate financial reporting”); id. at 1869 ("[M]ost evidence supports the ... conclusion that more independence means less financial monkey business”).
}

${ }^{68}$ See Gordon, supra note __ at 1504 (the "best-developed evidence" is a "positive association between board independence and financial reporting accuracy" [and why it occurs is not certain] but "some studies suggest it could be through the independent audit committee").

${ }^{69}$ Mark S. Beasley, An Empirical Analysis of the Relation Between the Board of Director Composition and Financial Statement Fraud, 71 ACCT. REV. 443, 455 (1996) (negative association between accounting fraud and relative board independence); see also Mark S. Beasley et al., Fraudulent Financial Reporting: Consideration of Industry Traits and Corporate Governance Mechanisms, 14 ACCT. HORIZONS 441, 452 (2000) (negative association between independence and fraud in several industries); Hatice Uzun et al., Board Composition and Corporate Fraud, Fin. ANALYsts J., May-June 2004, at 33 (similar relationship using broader proxy for fraud).

${ }^{70}$ Patricia M. Dechow et al., Causes and Consequences of Earnings Manipulation: An Analysis of Firms Subject to Enforcement Actions by the SEC, 13 CONTEMP. ACCT. RES. 1, 21 (1996) (comparing firms with high likelihood of accounting fraud, as signaled by SEC enforcement action, with a control group of firms); David W. Wright, Evidence on the Relation Between Corporate Governance Characteristics and the Quality of Financial Reporting (May 1996), working paper www.ssrn.com/abstract=10138 (firms facing SEC enforcement actions sport less audit committee independence compared to sample of industry or size cohort); Eric Helland \& Michael E. Sykuta, Who's Monitoring the Monitor? Do Outside Directors Protect Shareholders' Interests?, 40 FIN. REv. 155, 171 (2005) (association between independence and fewer shareholder lawsuits).

${ }^{71}$ April Klein, Audit Committee, Board of Director Characteristics, and Earnings Management, $33 \mathrm{~J}$. ACCT. \& ECON. 375, 387 (2002) (negative association between board independence and abnormal accruals); Sarah E. McVay et al., Trading Incentives to Meet the Analyst Forecast, 11 ReV. AcCT. STUD. 575, 575 (2006) (earnings management "is weaker in the presence of an independent board"). 
finding that independence is associated with lower levels of earnings manipulation or accounting fraud. ${ }^{72}$

The idea that audit committee expertise might contribute to more accurate financial reporting is intuitive. ${ }^{73}$ This intuition was the basis for early interest in promoting expertise, including the Treadway Commission's recommendations. ${ }^{74}$ Experimental studies show the relativity of expertise, ranging from the command of rudimentary knowledge ("literacy") to experiential knowledge derived from extensive applications in practice ("actual expertise"). ${ }^{75}$ Also intuitively, neither independence nor expertise contributes to results unless those commanding such traits have power to implement recommendations ${ }^{76}$ (a result that SOX's structural audit committee reforms make promising).

Empirical evidence supports these intuitions. Extensive research investigates the correlation between various conceptions of audit committee expertise and related proxies for financial reporting quality (sometimes thought of as audit committee effectiveness). Studies show an inverse relationship between expertise and likelihood of: financial

${ }^{72}$ Jeffrey Cohen, Ganesh Krishnamoorthy \& Arnold M. Wright, The Corporate Governance Mosaic and Financial Reporting Quality, 23 J. AсCT. LiT. 87, 99-102 (2004) (surveying studies of relationship between governance characteristics, especially of audit committee independence, and earnings manipulation or fraud); compare Klein, Audit Committee, Board of Director Characteristics, and Earnings Management, supra note __ (association between abnormal accruals and independent directors but "no meaningful relation between abnormal accruals and having an audit committee comprised solely of independent directors").

${ }^{73}$ E.g., Stephen A. Scarpati, CPAs as Audit Committee Members, 196 J. AcCounTANCY 32 (2003); F. Todd DeZoort, An Investigation of Audit Committees' Oversight Responsibilities, 33 ABACus 208 (1997); Kannan Raghunandan \& William J. Read, The State of Audit Committees, 191 J. AccounTANCY 57 (2001); Kannan Raghunandan, William J. Read \& Dasaratha V. Rama, Audit Committee Composition, "Gray Directors," and Interaction with Internal Auditing, 15 AcCT. HoRIZONS 105 (2001); Dorothy A. McMullen \& Kannan Raghunandan, Enhancing Audit Committee Effectiveness, J. AccounTANCY 182 (1996) (companies with deficient financial reporting less likely to have CPAs on audit committee).

${ }^{74}$ See I. Bull \& Florence C. Sharp, Advising Clients on Treadway Audit Committee Recommendations, 167 J. ACCOUNTANCY 46 (1989).

${ }^{75}$ See Linda S. McDaniel et al., Evaluating Financial Reporting Quality: The Effects of Financial Expertise vs. Financial Literacy, 77 AcCT. REv. 139 (Supp. 2002) (experimental research using audit managers as "experts" and Executive MBA graduates as "literates" and finding that experts are better than literates at evaluating financial reporting quality).

${ }^{76}$ See Lawrence P. Kalbers \& Timothy J. Fogarty, Audit Committee Effectiveness: An Empirical Investigation of the Contribution of Power, 12 Auditing: J. PRAC. \& THEORY 24 (1993) (examining relation between audit committee power and effectiveness, finding that "expert power" is highly associated with financial reporting effectiveness). The internal control apparatus within an enterprise also has a bearing on the effectiveness of both corporate governance and financial reporting. See Robert A. Prentice, Sarbanes-Oxley: The Evidence Regarding Section 404, 29 CARDOZO L. REV. _ _ (forthcoming 2007), available at www.ssrn.com/abstract=991295 (manuscript at 12-22) (reviewing empirical studies concentrating on the association between internal control aspects of Sarbanes-Oxley and various proxies for corporate governance and reporting effectiveness). 
reporting irregularities, ${ }^{77}$ artificial earnings management, ${ }^{78}$ fraud $^{79}$ and restatements. ${ }^{80}$ Various degrees of expertise also associate with higher financial statement quality, ${ }^{81}$ more conservative accounting ${ }^{82}$ and a propensity to provide or update managerial forecasts containing adverse rather than favorable news. ${ }^{83}$ Studies show that greater expertise is associated with less-frequent suspicious auditor switching ${ }^{84}$ and lower likelihood of material weaknesses in internal controls. ${ }^{85}$

Recent research examines more closely various conceptions of audit committee expertise. This is motivated by debates concerning how to define expertise, especially by comparing the SEC's initial and revised definitions of expertise for audit committees. ${ }^{86}$ Evidence is strong that there is a correlation between accounting expertise and high quality financial statements and audit committee effectiveness. ${ }^{87}$ There is also some (but

77 See Dorothy A. McMullen \& Kannan Raghunandan, Enhancing Audit Committee Effectiveness, 182 J. ACCOUNTANCY 79 (1996).

${ }^{78}$ See Biao Xie et al., Earnings Management and Corporate Governance: The Role of the Board and the Audit Committee, 9 J. Corp. FIN. 295 (2003).

79 See Anup Agrawal \& Sahiba Chadha, Corporate Governance and Accounting Scandals, 48 J. L. \& ECON. 371 (2005).

${ }^{80}$ See Lawrence J. Abbott, et al., Audit Committee Characteristics and Restatements, 23 AuDITING: J. PRAC. THEORY 69 (2004).

${ }^{81}$ See Andrew J. Felo, Srinivasan Krishanmurthy \& Steven A. Solieri, Audit Committee Characteristics and the Perceived Quality of Financial Reporting: An Empirical Analysis (working paper 2003).

${ }^{82}$ See Gopal V. Krishnan \& Gnanakumar Visvanathan, Does the Sox Definition of an Accounting Expert Matter? The Association between Audit Committee Director's Expertise and Conservatism, http://www.ssrn.com/abstract=866884.

${ }^{83}$ See L. Karamanou \& Nicos Vafeas, The Association between Corporate Boards, Audit Committees, and Management Earnings Forecasts: An Empirical Analysis, 43 J. ACCT. RES. 453 (2005) (propensity to update forecasts for bad news more likely when audit committee boasts expertise).

${ }^{84}$ See Deborah Archambeault \& F. Todd DeZoort, Auditor Opinion Shopping and the Audit Committee: An Analysis of Suspicious Auditor Switches, 5 InT’L J. ACCT. 33 (2001).

${ }^{85}$ See Yan Zhang et al, Audit Committee Quality, Auditor Independence and Internal Control Weaknesses, J. ACCT. \& PuBliC POLICY (2006) (SOX internal control weakness more likely for firms with audit committees boasting less accounting financial expertise).

${ }^{86}$ As discussed above, SOX and the SEC first floated a narrow definition of expertise limited to accounting expertise but the SEC, under pressure, expanded it to include other kinds of financial expertise (nonaccounting financial expertise) as well as expertise in supervising accountants and other financial experts (non-financial expertise).

87 See, e.g., Dan Dhaliwal, Vic Naiker \& Farshid Navissi, The Association between Audit Committee Accounting Expertise, Corporate Governance and Accruals Quality: An Empirical Analysis (Jan. 2006); Joseph V. Carcello, Carl W. Hollingsworth, April Klein \& Terry L. Neal, Audit Committee Financial Expertise, Competing Corporate Governance Mechanisms, and Earnings Management (Feb. 2006). 
limited) evidence of a correlation between non-accounting financial expertise and those virtues. $^{88}$ Evidence is strong that there is no particular correlation between non-financial expertise and various measures of financial statement reliability or general audit committee effectiveness. ${ }^{89}$

Some of this research emphasizes normative implications. Several studies expressly support the SEC's original narrow definition of expertise as opposed to the broader definition it later adopted under pressure. Classifying audit committee members as boasting accounting, non-accounting financial and other non-financial expertise, one study finds a significant positive correlation between accounting expertise and accruals quality, but no such correlation with the other two kinds of expertise. ${ }^{90}$ The prescription is to favor SOX's and the SEC's first narrow definition-recognizing that other committee features can influence effectiveness too. ${ }^{91}$ Using similar definitions, another study likewise finds a correlation between accounting expertise and accounting conservatism, but no correlation between other expertise and that quality-also expressly supporting SOX's and the SEC's original narrow definition. ${ }^{92}$

Another study stating normative implications finds the strongest correlation is with accounting expertise, following similar definitional classifications. ${ }^{93}$ Accounting expertise and some non-accounting financial expertise are associated with lesser earnings management for firms with weak alternate corporate governance mechanisms. But

\footnotetext{
${ }^{88}$ See, e.g., Jean Bedard, Sonda Marrakchi Chtourou \& Lucie Courteau, The Effect of Audit Committee Expertise, Independence and Activity on Aggressive Earnings Management, 23 AuDITING: J. PRAC. \& THEORY 13 (2004); Lawrence J. Abbott et al., Audit Committee Characteristics and Financial Misstatement: A Study of the Efficacy of Certain Blue Ribbon Committee Recommendations (Mar. 2002) (unpublished manuscript), available at http://ssrn.com/abstract=319125.
}

${ }^{89}$ See, e.g., Joseph V. Carcello \& Terry L. Neal, Audit Committee Characteristics and Auditor Dismissals Following "New" Going Concern Reports, 78 ACCT. REV. 95 (2003); Robert C. Anderson et al., Board Characteristics, Accounting Report Integrity and the Cost of Debt, 37 J. ACCT. \& ECON. 315 (2004).

90 Dhaliwal, Naiker \& Navissi, supra note __. Following an emerging standardization of these classifications in the empirical literature, the study delimits them as follows: accounting expertise is current or past experience as CPA, CFO, comptroller, VP finance or "any other major accounting positions"; finance expertise is current or past experience as investment banker, financial analyst or "any other financial management roles;" and supervisory expertise is current or past experience as CEO or company president or the like. Dhaliwal, Naiker \& Navissi, supra note

${ }^{91}$ Notably, the Dhaliwal, Naiker \& Navissi study also finds significant positive interaction between audit committee accounting expertise and attributes that signal strong audit committee governance (namely independence, a relatively larger size and more frequent meetings). Dhaliwal, Naiker \& Navissi, supra note

${ }^{92}$ Gopal V. Krishnan \& Gnanakumar Visvanathan, Does the Sox Definition of an Accounting Expert Matter? The Association between Audit Committee Director's Expertise and Conservatism, http://www.ssrn.com/abstract=866884.

${ }^{93}$ Joseph V. Carcello, Carl W. Hollingsworth, April Klein \& Terry Neal, Audit Committee Financial Expertise, Competing Corporate Governance Mechanisms, and Earnings Management (Feb. 2006). 
independent audit committee members with financial expertise are most successful in mitigating earnings management. The researchers emphasize that "alternative corporate governance mechanisms are an effective substitute for audit committee financial expertise."94 The normative implication: firms should have flexibility to choose the governance mechanisms that fit their unique situations, recognizing the likely value of accounting expertise on audit committees.

Research also considers market reaction to adding various kinds of expertise to audit committees. A widely-cited study found favorable market reactions to companies naming new audit committee members boasting accounting expertise, especially when other good governance attributes exist, but no reaction to non-accounting expertise. ${ }^{95}$ These researchers emphasize that the findings are consistent with accounting expertise on audit committees improving corporate governance, but only when the expert and the corporation's other governance attributes empower experts to make a difference. ${ }^{96}$ This market-based study thus is consistent with the other empirical research as well as longstanding intuition that accountants will contribute accounting expertise when empowered to do so.

Given the normative prescriptions of such studies, it's worth noting that some studies find a correlation between broader conceptions of expertise and desirable financial reporting traits. For example, one study found a correlation between financial and governance expertise and lower levels of earnings management and even some correlation between other kinds of firm-specific expertise and that quality. ${ }^{97}$ This study's findings are also generally consistent with the view that independent directors contribute to quality financial reporting.

In summary, there are many ways to promote financial reporting quality and audit committee effectiveness, including through independence, accounting expertise, and possibly other kinds of expertise. This may suggest that legal mandates are neither wise nor necessary. ${ }^{98}$ Indeed, despite the empirical evidence suggesting that audit committee accounting experts contribute to financial statement quality, there are contrasting

${ }^{94} I d$.

${ }^{95}$ Mark DeFond, Rebecca N. Hann \& Xuesong Hu, Does the Market Value Financial Expertise on Audit Committees of Boards of Directors?, 43 J. ACCT. RES. 153 (2005).

${ }^{96} I d$.

${ }^{97}$ See Jean Bedard, Sonda Marrakchi Chtourou \& Lucie Courteau, The Effect of Audit Committee Expertise, Independence and Activity on Aggressive Earnings Management, 23 AudiTing: J. PRAC. \& THEORY 13 (2004).

${ }^{98}$ See Roberta Romano, The Sarbanes-Oxley Act and the Making of Quack Corporate Governance, 114 YALE L. J. 1521 (2005) (making this point in light of the lack of evidence supporting association between independence and firm performance and the mixed evidence on the association between audit committee independence and financial reporting quality although not exploring the evidence concerning audit committee expertise and financial reporting quality). 
scenarios. At Enron, for example, both independent directors and experts on its audit committee failed to catch manifest irregularities. ${ }^{99}$ Even so, the evidence suggests that some combinations are stronger and others weaker, with the optimal combining independence and accounting expertise. Yet numerous policy and legal issues arise from the intuition and evidence, to which the next Part turns.

\section{THE FUTURE ROLE OF EXPERTISE}

A normative implication of the empirical evidence on expertise is to encourageif not mandate-the appointment of accounting experts to audit committees. After all, CEOs - and many other business experts - rarely have knowledge of generally accepted accounting principles (GAAP), generally accepted auditing standards (GAAS) or rules and regulations of the SEC and applicable securities laws. ${ }^{100}$

Objections to a mandatory or even hortatory commitment to board expertise, including on audit committees, concern the considerable burden of expectations that would befall those members. The burden is significant as a practical matter given lack of specification of what those expectations should be. It is exacerbated by uncertainty as to what legal consequences follow from the fact that a director has expertise. The following considers each of these problems in turn.

\section{A. Specifications}

Rediscovering the value expertise underscores a significant shift at the basic level of specifying the expertise that boards of directors should wield. Before the SOX era spawned interest in substantive expertise, theorizing about expected expertise was limited. Professor Eugene Fama offered the general theory that independent directors contributed expertise in "decision control."101 It is possible that decision control is the expertise that all independent directors offer, ${ }^{102}$ yet that imagines boards as monoliths without attention to particular skills that, under the division of labor, contribute individualized value.

While focusing on expertise associated with quality financial reporting, SOX recognizes that directors, independent and otherwise, each can contribute different expertise. In the future, one should expect increased attention to other kinds of expertise that exploit the division of labor too, such as in recruiting business leadership through

\footnotetext{
${ }^{99}$ See William W. Bratton, Jr., Enron and the Dark Side of Shareholder Value, 76 TuL. L. Rev. 1275, 1333-38 (2002); Paul M. Healy \& Krishna G. Palepu, Governance and Intermediation Problems in Capital Markets: Evidence from the Fall of Enron (Harvard NOM Working Paper No. 02-27, Aug. 15, 2002), available at http://ssrn.com/abstract=325440.

${ }^{100}$ See Dennis Beresford, Take a Seat in the Boardroom, 200 J. AcCOUNTANCY 104 (2005).

${ }^{101}$ Fama, supra note

${ }^{102}$ For criticism, see Lucian Arye Bebchuk et al., Managerial Power and Rent Extraction in the Design of Executive Compensation, 69 U. CHI. L. REV. 751, 771 (2002).
} 
nominating committees boasting not merely independence but knowledge of relevant labor markets and designing compensation systems using directors who are not merely independent but knowledgeable on the subject. Sparked by SOX, the following focuses solely on specifying the expertise that it seems to contemplate in order to highlight both the importance and difficulty of doing so.

SOX appears to demand expertise to promote financial reporting quality. True, SOX covers much ground by tinkering with many aspects of corporate governance. But there is no doubt that SOX was inspired by problems with accounting and control systems and sought to respond with tools to improve both. ${ }^{103}$ Thus it emphasizes internal control, adding in its most elaborate provisions, Sections 103 and 404 concerning maintaining, certifying and auditing internal control. ${ }^{104}$ Many consider the rearrangement of the audit supervision function to be among SOX's most important changes. ${ }^{105}$ In short, SOX is about accounting and so the expertise on audit committees should be accounting expertise-not necessarily the broader conceptions reflected in the SEC's final definition.

The historical catalyst for independent directors and developments in intervening decades also supports this view. During the 1970s, and since SOX, the expertise expected from independent directors appears more in the nature of expertise in internal control systems designed to promote financial reporting quality and compliance with law. ${ }^{106}$ The 1970s bribery scandals that led to laws requiring internal control systems and independent directors were logical servants of compliance. In the late 1990s, even a Delaware court, in Caremark, ${ }^{107}$ questioned the continuing validity of the 1963 Graham decision that minimized director responsibilities over internal control. ${ }^{108}$

103 See Sarbanes-Oxley Act of 2002, Preamble.
${ }^{104}$ See Lawrence A. Cunningham, Facilitating Auditing's New Early Warning System: Control Disclosure, Auditor Liability and Safe Harbors, 55 HASTINGS L.J. 1449 (2004).

105 John C. Coffee, JR., GAtekeepers: The Role of the Professions in Corporate GovernanCE 367 (2006); Erica Beecher-Monas, Corporate Governance in the Wake of Enron: An Examination of the Audit Committee Solution to Corporate Fraud, 55 ADMIN. L. REV. 357 (2003); Bratton, Enron, Sarbanes-Oxley and Accounting, supra note , at $1034-36$.

106 See Melvin A. Eisenberg, The Board of Directors and Internal Control, 19 CARDOZO L. REV. 237 (1997); Michael P. Dooley, Two Models of Corporate Governance, 47 Bus. LAw. 461 (1992).

${ }^{107}$ In re Caremark Int'l Inc. Derivative Litig., 698 A.2d 959 (Del. Ch. 1996).

108 Caremark's language and subsequent Delaware court applications of it suggest that it poses no real liability threat to directors, see Stone v. Ritter, 911 A.2d 362 (Del. 2006), but Delaware law rarely does but its admonitions can play a norm-shaping function. See Melvin A. Eisenberg, Corporate Law and Social Norms, 99 Colum. L. Rev. 1253 (1999); Edward B. Rock, Saints and Sinners: How Does Delaware Corporate Law Work?, 44 UCLA L REV. 1009 (1997); David A. Skeel, Jr., Shaming in Corporate Law, 149 U. PA. L. REV. 1811 (2001). 
The demand for accounting expertise is reflected in audit committee charters widely adopted in SOX's wake. A survey of selected charters is revealing. First, there is substantial standardization of these documents across a variety of enterprises. ${ }^{109}$ Second, they tend to concentrate on fundamentals of accounting, along with internal controls. A reasonable inference from the objectives stated in these charters is that the implicit expectations can be met only by those with accounting expertise. ${ }^{110}$ It is likely that they require an understanding not only of accounting principles and inherent need for estimates but also (1) the various maneuvers available to massage reported accounting results and (2) relative conservatism and the consequences of achieving any given level of conservatism.

Despite this plausible claim that SOX and current audit committee members seek to use accounting expertise and internal control to promote financial reporting quality, such statements are broad and conceal trade offs. Expertise may enable an enterprise to promote quality financial reporting in conformity with GAAP, GAAS and SEC regulations-including internal control requirements-but these subjects allow for considerable leeway in application. The following explores two examples of the challenges that result: (1) earnings management raises the issue of how involved audit committee accounting experts must be in substantive decisions that managers make in pursuing desired accounting results and (2) conservatism raises the issue of whose interests audit committee accounting experts should seek to promote.

1. Earnings Management. Managers can deliberately influence reported financial results through manipulation of discretionary accounting estimates and allocations (called “accounting earnings management”) or though manipulation of discretionary expenditures (referred to as "real earnings management"). ${ }^{111}$ Survey evidence indicates that managers engage in real earnings management when necessary to meet targeted or expected accounting results, such as earnings per share. ${ }^{112}$ Empirical evidence is strong

${ }^{109}$ See also Lawrence A. Cunningham, Law \& AcCounting: CASES AND MATERIALs 612-15 (2005) (presenting illustrative audit committee charter).

${ }^{110}$ See also Krishnan \& Visvanathan, supra note __ at __ (noting that audit committee charters are standardized, giving examples from Ruby Tuesday and eBay).

${ }^{111}$ See Sugata Roychowdhury, Management of Earnings Through the Manipulation of Real Activities that Affect Cash Flow From Operations (working paper 2005) (providing a model to measure real earnings management, relating levels of actual operating cash flows, discretionary expenditures such as R\&D and SG\&A, and production costs to normal levels estimated by industry and company experience and finding evidence of real earnings management for sample of enterprises from 1987 to 2001). Real earnings management can be achieved through any means that enables the acceleration or delay of recognizing events, thus including decisions concerning investment, inventory, training and so on.

112 See John R. Graham, Campbell R. Harvey \& Shivaram Rajgopal, The Economic Implications of Corporate Financial Reporting, 40 J. AсCT. \& ECON. 3 (2005) and John R. Graham, Campbell R. Harvey \& Shivaram Rajgopal, Value Destruction and Financial Reporting Decisions (working paper 2006) (Fall 2003 survey reveals that CFOs think EPS is important and are willing to use real earnings management to meet expectations or to smooth, with $80 \%$ saying they would decrease discretionary spending on $\mathrm{R} \& \mathrm{D}$, advertising, and maintenance to meet earnings expectations and 55\% saying they would delay a positive net present value investment project to meet earnings expectations). 
that accounting expertise on audit committees reduces accounting earnings management. ${ }^{113}$ Empirical evidence concerning whether audit committee accounting expertise influences real earnings management is both limited ${ }^{114}$ and conflicting, with studies showing both absence ${ }^{115}$ and presence ${ }^{116}$ of a negative correlation.

Whether audit committee experts influence real earnings management may depend, in part, on whether they believe that is their responsibility, because no authority specifies what their purpose is. SOX, the SEC and the exchanges only suggest or require expert presence without saying anything about its purpose. Authoritative silence on the purpose of expertise leads to two competing views in the literature.

One view sees audit committees as monitors and enforcers, whose presence is solely to assure compliance with what law, accounting and regulations require. ${ }^{117}$ If so, then accounting earnings management is their bailiwick, but real earnings management is not. Under the other view, audit committee experts are present for the purposes of directing and monitoring the management of the enterprise, including decisions concerning internal resource allocation. ${ }^{118}$ That role includes understanding whether resource allocation decisions are driven by substantive business judgments concerning long-term value enhancement or by short-term aspirations or pressures to achieve designated accounting results such as meeting earnings per share expectations.

\footnotetext{
${ }^{113}$ See supra text accompanying notes

114 See Krishnan \& Visvanathan, supra note , at 34 ("there is limited evidence on whether audit committees are able to constrain real earnings management”).
}

115 See Carcello, Hollingsworth, Klein \& Neal, supra note (finding no negative association between audit committee expertise and real earnings management). This study actually finds a positive association between audit committee expertise and the component of real earnings management involving the level of discretionary expenditures. Id. at 5.

116 See Krishnan \& Visvanathan, supra note __, at 7 (finding negative association between audit committee accounting expertise and real earnings management); id. at 34 (greater audit committee accounting expertise “mitigates tendencies to manipulate earnings through real activities”).

${ }^{117}$ See Carcello, Hollingsworth, Klein \& Neal, supra note __ ("Since real earnings management is within the bounds of GAAP, we argue that it is not in the purview of the audit committee."); id. ("Real earnings management ... is not illegal[,] not a violation of financial reporting rules, and even if discovered would not result in charges of financial fraud or create cause for an earnings restatement. Thus, we argue that it is beyond the scope of the audit committee's responsibility to filter out real earnings management.”); id. at 29 (real earnings management "is generally not fraudulent and would be well within the accepted province of management's discretion”); see also Hillary A. Sale, Independent Directors as Securities Monitors, 61 BUS. LAW. 1375 (2006).

118 See Krishnan \& Visvanathan, supra note __, at 35 (also opining that audit committee member incentives to constrain real earnings management are the same as those for accounting earnings management: knowledge base, job expectations stated in charter plus litigation and reputation risk). 
The latter view seems compelling as a matter of law, logic and policy. As a matter of law, committee experts are directors too and directors are not excused from understanding, reviewing or even controlling internal firm resource allocationswhatever their specific purpose. As a matter of logic, the distinction between accounting earnings management and real earnings management is ultimately superficial-both are artificial exercises. Most importantly, as a matter of policy, evidence is strong that the post-SOX reduction in accounting earnings management has increased managerial appetite and resolve to pursue real earnings management. ${ }^{119}$ Determining that audit committee accounting experts should police accounting earnings management but not real earnings management would produce a policy backfire.

The backfire would be at least as serious as the problem that accounting earnings management presents, although the problems differ slightly. The problem with accounting earnings management is that investors are misled into sub-optimal capital allocation decisions that could result in investment losses. The problem with real earnings management is that managers deliberately commit to sub-optimal capital allocation decisions that almost certainly, although stealthily and indirectly, inflict investment losses on investors. ${ }^{120}$ Accordingly, the expectations and duties of audit committee experts should include controlling real earnings management precisely as much as accounting earnings management. ${ }^{121}$ At least, specification of expectations is in order.

2. Conservatism. A general definition of conservatism in accounting is a prudential preference, in the face of uncertainty, to understate economic reality rather than overstate it. ${ }^{122}$ In practice, this entails the understatement of net assets by more

\footnotetext{
${ }^{119}$ See Daniel A. Cohen, Aiyesha Dey \& Thomas Lys, Trends in Earnings Management in the Pre-and Post-Sarbanes Oxley Periods (working paper 2005) (finding post-SOX accounting earnings management has declined but real earnings management has increased); Carcello, Hollingsworth, Klein \& Neal, supra note — at 31 (findings suggest that accounting experts "can mitigate earnings management via discretionary accruals" but that managers "react by increasing real earnings management”).

${ }^{120}$ See Carcello, Hollingsworth, Klein \& Neal, supra note __ ("Real earnings management may diminish firm and shareholder value ... ”); Graham, Harvey \& Rajgopal, supra note

${ }^{121}$ See Graham, Harvey \& Rajgopal, supra note ___ (suggesting that boards and audit committees should exercise oversight to prevent managerial decisions that promote real earnings management while destroying corporate and shareholder value).

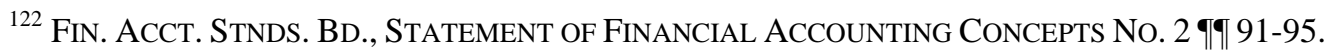


timely recognition of losses compared to gains. ${ }^{123}$ These conceptions can be unpacked by specifying the circumstances in which such asymmetric recognition can occur. ${ }^{124}$

Strong conservatism would describe a pervasive preference so that no or few circumstances depart from that norm, epitomized in such traditional dictums as the lower of cost or market principle. Weak conservatism would describe a limited preference so that numerous contexts allow departures from that kind of dictum, such as where fair value accounting allows using actual or estimated current fair market values for designated asset classes (like marketable securities or property, plant and equipment). Neutral conservatism would designate a median position between the extremes.

Different corporate constituencies have different appetites and demand for relative conservatism. ${ }^{125}$ Consider four classes of potential constituents: equity investors, debt investors, employees compensated using accounting-based bonus systems and society, governmental taxation being the proxy. All other things being equal, debt demands strong conservatism to protect downside risks, ${ }^{126}$ employees demand weak conservatism to exploit bonus payments ${ }^{127}$ and equity demands weak or neutral conservatism depending on time horizons and prevailing market conditions. ${ }^{128}$ While

\footnotetext{
${ }^{123}$ See Sudipta Basu, The Conservatism Principle and the Asymmetric Timeliness of Earnings, 24 J. AccT. \& ECON. 3 (1997). A variety of definitions of conservatism appear in the literature, including proxying it by the level of verification required to support recognition or measurement of an accounting item. The variety of definitions, and the range of emphasis placed on the principle, reflects the breadth of discretion in application.

124 The concept of conservatism also can be tested using a wide variety of proxies. See Krishnan \& Visvanathan, supra note _ _ at _ . In addition to asymmetric loss recognition, examples include bookto-market ratio; correlation between cash flows and contemporaneous accruals; and correlation between changes in current earnings and lagged changes in earnings. See Anne Beatty, Joseph Weber \& Jeff Yu, Conservatism and Debt (working paper Jan. 2006).

${ }^{125}$ See Langevoort, Social Construction of SOX, supra note _ _ at 1839 (“conservative financial reporting is comforting to creditors, shareholders, and others who see it as a disciplinary or monitoring tool [but with a] corresponding loss in accuracy. ... [C]onservative GAAP reporting on average understates the true economic value of the firm. . . . How much, if at all, conservative reporting deprives investors of useful information is controversial" (citing Anil Arya et al., Are Unmanaged Earnings Always Better for Shareholders?, 17 ACCT. HORIZONS 111 (Supp. 2003)).
}

${ }^{126}$ See William W. Bratton, Shareholder Value and Auditor Independence, 53 DukE L.J. 439, 477 (2003) (debt investors prefer conservative accounting because they do not enjoy capital appreciation and so concentrate on negative analysis of default risk and rely on hard assets for ultimate recovery). Other advantages of conservatism for debt investors include how resulting accounting would sooner signal adversity and trigger applicable remedial rights such as acceleration. See Raymond J. Ball, Ashok Robin \& Gil Sadka, Is Accounting Conservatism Due to Debt or Equity Markets? An International Test of "Contracting" and "Value Relevance" Theories of Accounting (working paper 2005).

${ }^{127}$ Other employees likely exhibit risk aversion akin to debt investors. See Bratton, Shareholder Value and Auditor Independence, supra note , at 477 .

${ }^{128}$ See Bratton, Shareholder Value and Auditor Independence, supra note _ _ at 455-63 (providing a taxonomy of equity investors arrayed according to their diverse types: speculators, investors, short-term holders, long-term holders, noise traders, fundamental value investors, dumb money, and smart money); id. 
government may prefer weak conservatism to maximize immediate tax revenue (setting aside supply-side effects), to minimize tax obligations enterprises prefer strong conservatism (to the extent that financial and tax accounting regimes are co-extensive). In whose interests shall audit committee accounting experts draw the conservatism line amid resulting trade-offs?

Two constraints ameliorate the magnitude of these trade-offs, but they are incomplete, leaving the question and significant challenges open. First, accounting standards established through formal standard setting limit the discretionary range. But they do not eliminate it. GAAP historically embedded a conservatism principle, generally favoring asymmetric recognition of losses compared to gains. But it allowed a range within which conservatism could be relatively stronger or weaker in designated contexts, such as estimating warranty reserves and loss contingencies. ${ }^{129}$ Moreover, GAAP is becoming less conservative through expanded use of fair value accounting and by moving away from traditional dictums such as the lower of cost or market principle. ${ }^{130}$ Accordingly, managers - and audit committee accounting experts-face choices along the conservatism continuum within existing standards and will have more discretion under broadening fair value standards.

Second, debt contract covenants can be used to supply conservatism that lenders demand, without regard to relative conservatism of official standards or decisions enterprises make when producing published financial statements. ${ }^{131}$ While there is some modest empirical evidence that lenders use covenants to do this, ${ }^{132}$ the weight of the evidence indicates that contractual modifications only partly satisfy lender demand for accounting conservatism. ${ }^{133}$ For example, studies show a positive correlation between

at 465-72 (illustrating range of shareholder demand functions using examples of relatively benign cookie jar reserves to more aggressive earnings management through the timing of revenue recognition and finding that even in the more extreme contexts the shareholder interest, subject to changing environments over time, “does not unite against management and aggressive accounting”)

129 See Cunningham, LAW \& Accounting, supra note , at (excerpting selections from relevant standards).

130 See Stanley Siegel, The Coming Revolution in Accounting: The Emergence of Fair Value as the Fundamental Principle of GAAP, 42 WAyne L. REV. 1839 (1996); Fin. ACCT. STNDS. BD., STATEMENT OF

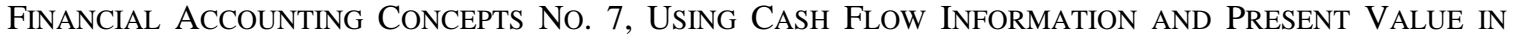
Accounting Measurements (Feb. 2000); Fin. Acct. Stnds. Bd., Statement of FinAncial Accounting StAndards No. 133, Accounting for Derivative Instruments and Hedging Activities, Statement of Financial Accounting Standards No. 133 (1998); Fin. ACCT. STNDS. BD., STATEMENT OF

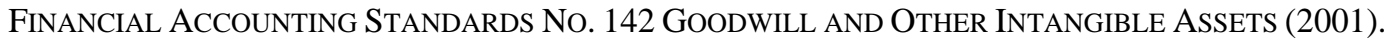

131 Debt contract terms invariably reflect conservatism, as where covenants count losses fully and credit gains only partly. See Beatty, Weber \& Yu, supra note

132 See Wayne R. Guay \& Robert E. Verrecchia, Discussion of Bushman and Piotroski and Theory of Conservative Accounting (working paper 2006).

133 Roy L. Watts, Conservatism in Accounting Part I: Explanations and Implications, 17 ACCT. HORIZONS 207 (2003); Roy L. Watts, Conservatism in Accounting Part II: Evidence and Research Opportunities, 17 AccT. Horizons 287 (2003); see also Raymond J. Ball, Ashok Robin \& Gil Sadka, Is Accounting 
contractual tailoring toward conservatism and conservative financial reporting apart from that tailoring. ${ }^{134}$ The costs of contracting are too great to meet lender demand for conservatism entirely by contract. ${ }^{135}$ The empirical results support conjectures and historical evidence that the conservatism principle in GAAP arose from lender demand for standardization of conservatism to reduce costs of contracting. ${ }^{136}$

Two other factors amplify the magnitude of the trade-offs, increasing their significance and accentuating the question of audit committee beneficiaries. First, managers are commonly those employees who are compensated according to accountingbased measurements. They have strong incentives against conservatism and essentially set its level. Again, this reality partly explains why US accounting standards historically embed the conservatism principle. ${ }^{137}$ Audit committee accounting experts have an important monitoring and control function to play in negotiating the competing demands for relative conservatism, particularly when managers have incentives to demand weak conservatism, at best. ${ }^{138}$

Second, equity investors exhibit demand for neutral to weak conservatism according to respective time horizons and market conditions. ${ }^{139}$ Short-term equity investors demand weaker conservatism, while long-term investors demand stronger conservatism. In periods of economic expansion and rising stock prices, equity investors

Conservatism Due to Debt or Equity Markets? An International Test of "Contracting" and "Value Relevance" Theories of Accounting (working paper 2005) (international data showing economies with larger debt than equity markets produce more conservative reports, implying that lender demand influences financial reporting outcomes).

${ }^{134}$ Beatty, Weber \& Yu, supra note

${ }^{135}$ Beatty, Weber \& Yu, supra note __ ("findings suggest that lenders may find it too costly to meet their demand for conservatism through contract modifications [so that] [a]s GAAP becomes less conservative, borrowers may be forced to make more conservative accounting choices within GAAP to avoid the costly modifications to contract GAAP.”).

${ }^{136}$ Roy L. Watts, A Proposal for Research on Conservatism (unpublished manuscript 1993); see also Fin. Acct. Stnds. BD., Statement of Financial ACCOUnting Concepts No. 2, Qualitative CHARACTERISTICS OF ACCOUNTING INFORMATION, 94 (1980) (noting a preference of lenders for conservative accounting).

${ }^{137}$ See Watts, Conservatism in Accounting Part I, supra note (conservatism facilitates monitoring of managers and contracts by constraining overpayments to managers); Watts, Conservatism in Accounting Part II supra note (same).

${ }^{138}$ If audit committee financial experts were compensated in any part using accounting-based measures, these functions would become more difficult to perform. The role of incentive compensation also points to the importance of related expertise — not so much independence - on the board compensation committee. It also suggests developing critical relationships between experts on the audit committee and compensation committee to coordinate tasks to achieve optimal enterprise policies.

139 Beatty, Weber \& Yu, supra note __ (noting how lenders demand conservative accounting given asymmetric nature of claims, in contrast to equity which prefer symmetric or neutral accounting). 
tend to demand weaker conservatism and in economic downturns and bear markets preferences tend to return to stronger conservatism. ${ }^{140}$ This variation adds competing demand functions that audit committee accounting experts should be expected to balance.

Finally, the tax function cuts both ways. ${ }^{141}$ Supply-side theory aside, government may seek weaker conservatism in corporate financial reporting but other constituentsequity, debt, and employees-prefer comparatively stronger conservatism. At least this is true to the extent that GAAP and tax accounting impose uniform requirements, which is not always the case in the United States. But there are important contexts in which the two requirements are co-extensive, as with inventory accounting to take an example for merchandising enterprises. And empirical evidence demonstrates that tax-paying enterprises use more conservative accounting than tax-exempt entities. ${ }^{142}$ The result is an additional factor that influences the degree of conservatism that financial reports supply_and additional challenges for audit committee financial experts.

This is not to suggest that the trade-offs are un-resolvable. They frequently are resolved, among standard-setters and preparers alike. ${ }^{143}$ The critical point is that the demand for conservatism is relative and varies across corporate constituencies. GAAP reposes extensive discretion, even under its conservatism principle, and contracts do not satisfy all lender demand for conservatism. Conflicting interests are acute for managers enjoying accounting-based bonuses. Resolving these trade-offs suggests an important role for audit committee accounting experts even though authoritative guidance is lacking. ${ }^{144}$

To the extent that such experts are expected to perform new functions in the postSOX environment, clarifying these trade-offs would be desirable. In theory, the prescription may simply be that, as directors, the audit committee should act in the interests of shareholders. ${ }^{145}$ But shareholder demand for conservatism varies across shareholder types and with market conditions. And the greater the bias for weak

\footnotetext{
${ }^{140}$ Bratton, Shareholder Value and Auditor Independence, supra note __, at 455-63.

${ }^{141}$ See Watts, Conservatism in Accounting Part I, supra note

${ }^{142}$ Watts, Conservatism in Accounting Part II supra note ___ (empirical evidence showing that tax paying enterprises use more conservative accounting than tax exempt entities).
}

143 See Watts, Conservatism in Accounting Part I, supra note __ (lender demand drives conservatism in law, standards, contracts, and practice; FASB and reporting enterprises all balance competing demands of equity and debt when setting and applying standards); Watts, Conservatism in Accounting Part II supra note __ (same).

144 See Krishnan \& Visvanathan, supra note ___ (despite importance of conservatism principle, there is "limited empirical evidence of the relation between audit committee characteristics and conservatism").

145 Cf. Lynn A. Stout, The Investor Confidence Game, 68 BROOKLYN L. REV. 407, 433-34, n. 71 (2002); Homer Kripke, The SEC, the Accountants, Some Myths and Some Realities, 45 N.Y.U. L. REV. 1151, 118891 (1970). 
conservatism, the greater is the managerial discretion. ${ }^{146}$ The new expertise on audit committees is intended to address managerial abuse of accounting discretion. This opens an alternative prescription: audit committee accounting experts have duties akin to those of auditors, meaning duties owed equally to shareholders and debt investors. ${ }^{147}$

These plausible alternatives suggest that the need is acute to clarify to whom audit committee accounting experts should be beholden. This inquiry is not to say that all audit committees should work to supply any particular level of conservatism or that law should supply the incentives to achieve such an objective. The exact demand and supply of conservatism varies among enterprises and across time according to varying capital structures and constituency demographics (including use of accounting-based bonus compensation and tax status).

Moreover, there is no way for accounting standards or external auditors to define the optimal supply and demand intercept in general or for a particular enterprise. But someone must exercise the resulting discretion among competing trade-offs. Managers do so in the first instance, but isn't it reasonable to ask experts within the enterprise to promote the optimal supply in response to varying demand? If so, the logical persons to do so are audit committee accounting experts. This does not ipso facto warrant judicial or regulatory intrusion into those decisions. On the contrary, if directors command expertise, judges and regulators-lacking it — should grant them as much latitude that independent directors have enjoyed for four decades.

The next section pursues this line of inquiry further, but before proceeding the observation concerning fair value accounting mentioned above bears elaboration. Conservative accounting traditions, such as the lower of cost or market principle, emphasize reliability over relevance when these traits are at odds. Fair value accounting is not conservative, being symmetrical to gains and losses and having no preference for lower or higher asset amounts. It purports to emphasize relevance over reliability. But, as noted, relevance may differ across constituents. Fair value accounting may be more “relevant” to equity investors and less relevant to debt investors. ${ }^{148}$

Yet even this proposition is doubtful, because fair value accounting simply uses prevailing valuations over other measures. Those values may not be relevant either to equity investors or debt investors (or any other constituents). Prevailing valuations are drawn from market transactions, if available, and from managerial estimates, if they are

\footnotetext{
146 See Faith Stevelman Kahn, Transparency and Accountability: Rethinking Corporate Fiduciary Law's Relevance to Corporate Disclosure, 34 GA. L. REV. 505, 507-18 (2000); Melvin A. Eisenberg, Legal Models of Management Structure in the Modern Corporation: Officers, Directors, and Accountants, 63 CAL. L. REV. 375, 417-19, 424-30 (1975).

147 See United States v. Arthur Young \& Co., 465 U.S. 805 (1984) ("The independent public accountant performing this special [public] function owes ultimate allegiance to the corporation's creditors and stockholders, as well as to the investing public.”)

${ }^{148}$ See Bratton, Shareholder Value and Auditor Independence, supra note at $478-79$.
} 
not. That expands managerial discretion and points to an important particular function for audit committee experts: to police fair value assumptions. The move towards fair value accounting thus will underscore the challenge for audit committee experts in determining their purpose and how best to meet it.

\section{B. Adjustments}

Audit committee accounting experts add value to corporate governance, yet receive no special benefits from contributing it compared to other directors and can face disincentives and threatened penalties. Both points require review. The following first explores disincentives that arise from the curious but common habits of celebrating independence, rewarding it over expertise, and holding that independence and expertise are mutually exclusive. Discussion then explores how law, especially Delaware corporate law, reinforces these biases by rewarding independence and penalizing expertise.

1. Compatibility. It is customary to observe a trade-off between director independence and director expertise. This relationship may hold for expertise that arises from corporate knowledge commanded only by senior executives. That kind of expertise, which may be called "status expertise," is mutually exclusive with attributes of detachment associated with most definitions of independence. Both sorts of directors contribute different kinds of value. The status expert may have greater ability than the outsider to identify excesses or duplicities of a CEO. The outsider may have greater freedom or capacity to act on that ability to interdict CEO shenanigans. Not only are the roles mutually exclusive in this sense they are also mutually complementary. The challenge is to find the optimal combination of these different kinds of expertise. ${ }^{149}$

The customary trade-off analysis has less force when expertise is considered as substantive command of a specialized field of knowledge, such as accounting. A director having no other affiliation with a corporation and providing accounting expertise presents none of the trade-offs between independence and that particular kind of expertise. Rather, the independent expert director adds mutually complementary value by bringing detachment, along with useful knowledge. Considering the weight of empirical evidence, the value that independence alone adds is tenuous compared to the strong contributions to quality financial reporting that independence plus accounting expertise makes. ${ }^{150}$

Seen in this light, existing federal law and exchange rules are unobjectionable. They leave corporations with substantial flexibility to achieve optimal board design.

\footnotetext{
${ }^{149}$ See Richard A. Epstein, In Defense of the Corporation, 2004 NZ L. REV. 707, 719 (2004) (stating that the optimal combination may be determined by thinking of the relationship between the marginal cost and the marginal benefit of an additional independent director compared to inside directors).

150 This remains so even if independence alone may contribute advantages to corporate governance that elude capture in statistical models testing its association with corporate performance, supra text accompanying notes ___ _ and despite how independence alone sometimes associates with financial reporting quality, supra text accompanying notes
} 
Independence is rewarded in certain circumstances, such as concerning executive compensation and taxation matters at the board level. ${ }^{151}$ It is addressed by SOX's rules speaking to audit committee obligations. ${ }^{152}$ But companies are free to have as many or as few independent directors as they wish. ${ }^{153}$ They are also free to have any number and type of persons wielding any variety of expertise. Although SOX's have-or-disclose provision encourages having experts on audit committees and exchange rules require some expertise, neither definition of expertise is rigorous. Further, federal law provides that designation of an audit committee member as such an expert imposes no greater or different duty or liability risk on that director compared to other directors. ${ }^{154}$

Despite the empirical reality and federal law flexibility, it may be tempting to believe that the customary trade off between independence and status expertise carries over to the context of substantive expertise. In some federal securities law contexts and in exchange rules, the definition of independence concentrates on the amount of money and benefits a person receives in various capacities from the corporation. Too much is said to impair independence. For example, exchange rules provide that one loses independence if income from advisory, consulting or related activities exceeds designated dollar amounts (\$60,000 under Nasdaq rules and \$100,000 for NYSE companies). ${ }^{155}$

SOX goes further, saying that independence and expertise are mutually exclusive as a functional matter, denying that anyone can be independent if performing expert services, outside a directorial capacity, for a given corporation. One corporate governance scholar testified before Congress that if a person is to provide consulting services, he should be retained as a consultant, and if he is to provide directorial services, he is to be nominated and elected as a director; in binary fashion, the witness testified that "You cannot blend the two."156 While this view is congruent with the customary tradeoff applicable to outsiders compared to those with status expertise (insiders), it is harder to square with the injection of substantive expertise where that trade-off dissolves.

\footnotetext{
${ }^{151}$ See supra text accompanying notes

${ }^{152}$ See supra text accompanying notes

153 See, e.g., Charu G. Raheja, Determinants of Board Size and Composition: A Theory of Corporate Boards, 40 J. Fin. \& QuAnT. ANALY. 283 (2005); Dan R. Dalton, Number of Directors and Financial Performance: A Meta-Analysis, 42 ACAD. MGMT. J. 674, 676 (1999) (surveying studies); Bhagat \& Black, The Uncertain Relationship, supra note __, at 941-42 (summarizing studies suggesting difficulty in establishing optimal size).

154 See SEC Release (Jan. 23, 2003) (text accompanying notes 34-38 explaining inclusion of safe harbor against exposing audit committee financial expert to any different legal liability than other directors and expressing the opinion that this should obtain under both federal securities laws and state corporation laws).

${ }^{155}$ Nasdaq Rule __ _ NYSE Rule

156 See Douglas M. Branson, Too Many Bells? Too Many Whistles? Corporate Governance in the PostEnron, Post-WorldCom Era, 58 S.C. L. REV. 65, 82-90 (2006) (quoting testimony of Professor Charles Elson, University of Delaware).
} 
An expert in accounting remains an expert in accounting when serving either as a director or as a consultant. Treating the activities as mutually exclusive gives content to the makeweight arguments opposing the SEC's original definition of the relevant expertise: fewer qualified people will be available and attracting them will absorb resources from other recruiting efforts. ${ }^{157}$ Corporations that recognize the value of expertise among directors will pay expert directors more-and classify payments as director compensation, not outside compensation. ${ }^{158}$ This reveals the constraints as formalistic (evidenced further by how exchange rules use fixed dollar figures for all directors rather than specifying compensation in meaningful terms such as a percentage of a person's adjusted gross income or net worth).

In such an environment, experts may prefer consulting to serving as members of a board of directors. Consultancy became an increasingly appealing line of work throughout the period of the monitoring board's ascendancy, which may be explained by the decline of interest in board expertise as the advisory model ceded to the monitoring model. $^{159}$ The appeal of consulting was reinforced by how consultants can serve in capacities that are equivalent to other gatekeepers-including independent directors, auditors, and lawyers - but without associated burdens or liability risks. ${ }^{160}$ Under the mutually exclusive approach, rules drive more experts off of boards and into consulting. Yet if expertise is desired on boards-as intuition, evidence and brewing change suggests - this framework requires adjustment. This is not to say that pristine definitions of independence must be forsaken, but to appreciate that zealous commitment to such purity carries a higher price than seems to be appreciated.

2. Incentives. More acute talent pool contraction arises from the strange reality that, in Delaware at least, independent directors enjoy extraordinary deference and face essentially no risk of judicial rebuke whereas expert directors are held to a higher standard of performance. These strange consequences follow from the awkward structure of director duties, which traditionally are classified as the duties of loyalty and care. ${ }^{161}$

\footnotetext{
${ }^{157}$ See supra text accompanying notes

158 See Clarke, Three Models of the Independent Director, supra note at $80 \& 84$
}

${ }^{159}$ See Gordon, supra note __, at 1513-14 \& n. 185 (the “advisory board . . . included . . . knowledgeable parties [who] could serve as a useful sounding board for the CEO, a kitchen cabinet, and could provide expertise ... . In an important sense, boards were an extension of management. . . . Thus another way to understand the movement from the advisory to the monitoring board is in terms of the rise of consultants, who can better provide cross-industry expertise and strategic counseling than board members recruited by the CEO.”).

160 See Christopher D. McKenna, The World’s Newest Profession: MAnagement Consulting in THE TWEnTIETH CEnTURY (2006). True, also, expert consulting firms can face liability risks for breach of contract or perhaps negligence when advice they give or projects they contribute backfire in ways that breach contracts or constitute torts. But that kind of liability exposure differs considerably from imposed on recognized gatekeepers. Id.

${ }^{161}$ More recently, a splinter duty that Delaware courts call good faith has appeared, although it is in fact a longstanding component of the other duties. See Melvin A. Eisenberg, The Duty of Good Faith in Corporate Law, 31 DeL. J. CORP. L. 1 (2005); see also Stone v. Ritter, 911 A.2d 362 (Del. 2006) 
Allegations of loyalty breaches are defended by showing independence and that showing enables invoking the business judgment rule under which discharge of the duty of care is presumed. So directors able to establish their independence are rewarded with complete deference under state law. The theory of this deference is that judges are not competent to make business decisions (or at least are less competent than independent directors).

In contrast, a director who is an expert suffers a burden rather than enjoying a benefit. A director expert in financial matters, for example, is expected to exercise that expertise. If one does not, that weakens the defense against allegations of breaching any fiduciary duty. ${ }^{162}$ The doctrine purports to enable judicial inferences from unexercised expertise that a person has acted with volition-with scienter using securities law parlance or in breach of the duty of loyalty in corporate law terms. Thus directors are penalized for commanding expertise but rewarded for independence.

Rewarding ignorance over knowledge is ironic. Moreover, to hold an expert director liable for failing to exercise expertise, a judge must have first decided, as a substantive matter, that a transaction was unfair, as when a merger price is too low. Irony thickens: directors who are independent but non-expert win deference from judges who say they lack business acumen while directors who are expert (without regard to independence) are second-guessed by those same (self-confessed) incompetent judges.

Incrementally punishing expertise while privileging independence may not matter much, of course, when few directors of any kind ever face personal liability for any decisions they make. But to capitalize on the recognized value of this expertise, policy should be alert to signals being sent. After all, signaling norms is one of the few important functions that Delaware courts perform. ${ }^{163}$

More important is how this stance conflicts with the concept of the division of labor. Incentives for independence may be desirable to promote the optimal mixture of independence and status expertise on a board and even to maintain some independence while adding substantive expertise. But as a matter of intuition, extensively supported by empirical evidence, incentives should be offered for substantive expertise too.

Benefits of the division of labor are advanced by substantive expertise in multiple disciplines not by increasing the outsider status of directors for the sake of achieving outsider status. Encouraging substantive expertise should be at least as important—or more so-than encouraging independence. Delaware courts have to wrestle with this problem. The solution could include following federal law, which provides that expert

(acknowledging that any duty of good faith is a component of the duty of loyalty).

${ }^{162}$ See In re Emerging Commc'ns, Inc., Civil Action No. A-16415, 2004 WL 1305745, at 40 (Del. Ch. May 3 , 2004, revised June 4, 2004) (expert director liable for failing to use financial expertise in testing financial fairness of cash out merger benefiting controlling shareholder).

${ }^{163}$ See supra note 
directors face no different or greater legal duty or liability risk than other directors. ${ }^{164}$ Attracting valuable expertise to boards of directors may depend on it.

\section{CONCLUSION}

Board independence has been the product of political compromise in most corporate governance debates during the past several generations. It has been possible for independence to be heralded so that all sides seem to get something from it-a reduction in agency costs for investors (both equity and debt) and protection of the interests of other corporate constituencies and perhaps society. One consequence of the political dimension is absence of consensus as to exactly what role independent directors are to play. While definitions of independence are regularly rewritten, no one knows exactly what independent directors are supposed to do and most evidence suggests that they don't do anything particularly well.

Gestures in SOX signal a sharp, yet still inchoate, conception of expertise on audit committees to promote superior financial reporting. Empirical evidence suggests that this works - directors with accounting expertise on audit committees are associated with more faithful financial reporting. However, it remains to specify the functions and expectations for these experts, including regarding the role experts are to play in policing real earnings management and the degree of conservatism to supply. Real earnings management raises questions about how involved such directors should be in nominally substantive business decisions that amount to subterfuges to achieve accounting results; conservatism compels asking for whom audit committee expert directors are trustees, particularly whether their conduct should be guided according to the interests of equity or debt investors.

Taking the empirical evidence on expertise together with the history of redefining independence, one can predict that, in the wake of future financial scandals, reforms will redefine expertise too. Reforms will most likely consider using the SEC's initial proposal and may event fiddle with the possibly of mandating expertise. Debate probably will have to address exactly what directors are supposed to do with their expertise. It seems prudent to begin these discussions before the next scandals erupt-which might even delay their timing, reduce their magnitude or tame their character.

\footnotetext{
${ }^{164}$ Notably, in its Release adopting final rules on audit committee financial experts, the SEC opined that neither Sarbanes-Oxley nor the SEC regulations should affect liability, under federal or state law, of directors designated as audit committee financial experts. See SEC Release (Jan. 23, 2003) (text accompanying notes 34-38).
} 